\title{
Web Based Application of Bus Inspection System in Pulo Gebang Bus Station
}

\author{
Hasbiyalloh \\ Faculty of Computer Science \\ Mercu Buana University \\ Jakarta, Indonesia
}

\author{
Fajar Masya \\ Faculty of Computer Science \\ Mercu Buana University \\ Jakarta, Indonesia
}

\begin{abstract}
Bus inspection is sequence activities to inspect administrative and technical elements for each bus that depart or exit from the bus station, which doing by the certified inspection officer / team, in order to guarantee the safety of traffic and road transport by avoiding everyone from the risk of accidents during traffic caused by humans, vehicles, roads and / or the environment [2]. The bus inspection activity in Pulo Gebang Bus Station which still uses a manual system that makes inspection files to fall apart, prone to loss or damage, difficult to find the history of bus inspection, and weak monitoring of inspection report. Based on this problem, this research is purposed to create a "Web Based Application of Bus Inspection System in Pulo Gebang Bus Station". This application is created using the method of developing linear sequential software (waterfall). Test conducted on this system is black box testing. By implementation of this application, solve the existing problems in the bus inspection process and simplify the work of employees and leader in Pulo Gebang Bus Station.
\end{abstract}

Keywords: Research, Web, Application, Bus Inspection, Pulo Gebang Bus Station.

\section{INTRODUCTION}

The Pulo Gebang Bus Station Management is the technical unit of the Transportation Department of DKI Jakarta Provincial Goverment, which has the main task of managing the Pulo Gebang Bus Station. Its main function is to serve public vehicles for interprovince intercity transportation combined with urban transportation [7].

To be able to provide transportation services that ensure traffic safety and road transportation with the avoidance of each person from accident risks during traffic caused by humans, vehicles, roads and / or the environment [2], it is necessary to check the health of bus driver and inspect each bus that will depart or exit from the bus station by the certified inspection officer / team which at least consists of inspection officer and civil servant investigators (PPNS).

At this time the inspection officer is still doing inspections manually by fill the inspection points into the inspection form, after the officer has finished inspecting, the form recapitulation of the bus inspection is rather longer because have to unite the forms from several officers who can different locations and have no a special officer to recapitulate bus inspection results, so the Head of Management difficult to know the results of detailed bus inspections every day.

Other weakneses are in the filing system of the inspection form because the forms are stored in the file cabinet without put a label with date and not separate where the passed inspection or failed inspection, it causes the files mixed, so if one day the inspection history is needed, officer will be difficult to find the bus inspection history, and the large number of inspection forms causes the files prone to lost / damaged.

Based on these problems, the right solution to solve the problem in the Pulo Gebang Bus Station is to create a "Web Based Application of Bus Inspection System in Pulo Gebang Bus Station".

\section{RESEARCH METHOD}

The location of research is in the Pulo Gebang Bus Station, at Jalan Sejajar Tol Sisi Timur KM.2 Pulo Gebang, Jakarta, Indonesia.

Supporting tools used in this research are hardware (personal computer) with the specifications of the Intel core-i5 Processor $3.20 \mathrm{GHz}, 4$ GB DDR-3 SDRAM RAM, 500 GB SATA Hard Drive 7200 rpm, Windows 1064 bit Operating System and software used are XAMPP Control Panel version 3.2.2, PhpMyAdmin, MySQL database, Google Chrome browser, Sublime Text 3 text editor, Microsoft Office Word 2016 and Microsoft Office Visio 2016.

The data collection techniques used are:

1. Library Study

Data was collected by studying, researching, and examining various literature from the library that are sourced from books, scientific journals, internet sites, and other reading related to the research conducted.

2. Field Study

Field study is a technique of collecting data by research and direct field survey of the research object. Field studies in this research at the Pulo Gebang Bus Station, are:

a. Interview

Interview is a technique to get answers from respondents by unilaterally questioning [1]. In this research, interview was conducted to the leader and several employees of the Pulo Gebang Bus Station according to the topic of the problem so it can get information and about the process of bus inspection.

b. Observation

Observation is a technique to get information by conducting careful observations and systematic recording [1]. In this research, observation was conducted by doing survey to the inspection activity and studying the flow of inspection process in the Pulo Gebang Bus Station.

The system development method used is the waterfall method. The stages of the waterfall method are: analisys, design, coding \& testing, implementation, and maintenance [8]. 


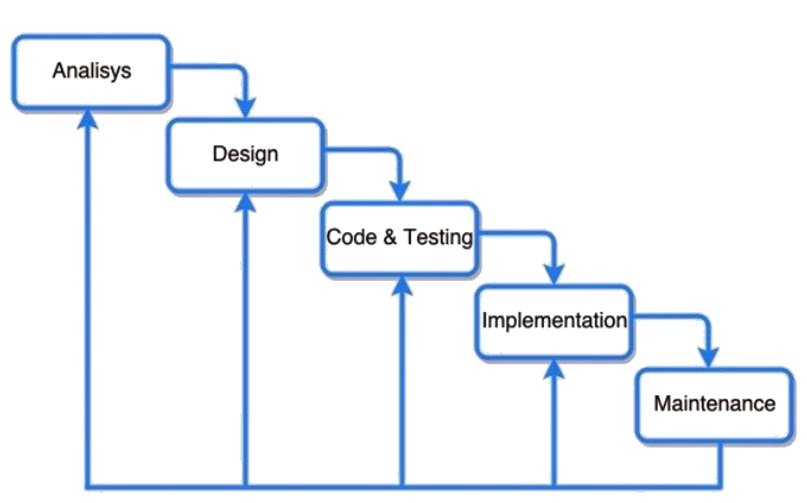

Fig 1. The waterfall stages

The stages of the waterfall method are explained as follows:

a. Analysis

Analysis is the first step to determine the design of application systems needed by the user to manage the website.

b. Design

The documentation produced from this system design stage includes: Use Case Diagrams, Activity Diagrams, Sequence Diagrams, and Class Diagrams.

c. Coding \& Testing.

Coding is writing the translation of system design that has been made into the form of commands understood by computers using programming languages. The programming language used is PHP with Codeigniter framework. Testing is to make sure all input output processes from the possibility of an error and a bug. So it can be immediately known and made improvements to the writing of the program code. Testing method used is Blackbox testing.

d. Implementation

The implementation of the application is the last stage where the developer implements an application that has been completed and tested before.

e. Maintenance

This step occurs after installation, and involves making modifications to the system or an individual component to alter attributes or improve performance.These modifications arise either due to change requests initiated by the customer, or defects uncovered during live use of the system. Client is provided with regular maintenance and support for the developed software.

\section{LITERATURE REVIEW}

The literature review method is a series of activities relating to the method of collecting data, reading and recording, and managing research materials [12]. Some related research are explained in the table below:

Table 1. Related research

\begin{tabular}{|l|l|}
\hline Researcher & Samsinar, Lis Suryadi \\
\hline $\begin{array}{l}\text { Journal } \\
\text { Title }\end{array}$ & $\begin{array}{l}\text { Desain Sistem Informasi Pengujian Kendaraan } \\
\text { Bermotor Pada UPT. PKB Kendaraan Khusus } \\
\text { Cilincing }\end{array}$ \\
\hline $\begin{array}{l}\text { Journal } \\
\text { Published }\end{array}$ & $\begin{array}{l}\text { Seminar Nasional Sistem Informasi Indonesia } \\
\text { (SESINDO), 22 September 2014 [10] }\end{array}$ \\
\hline Conclusion & $\begin{array}{l}\text { Conclusion: With the implementation of a } \\
\text { computerized system can minimize }\end{array}$ \\
\hline
\end{tabular}

\begin{tabular}{|c|c|}
\hline & $\begin{array}{l}\text { administrative process errors or the occurrence } \\
\text { of human error and simplify the work. } \\
\text { Adventages: The administration process is } \\
\text { computerized } \\
\text { Weaknesses: Still desktop based, not web- } \\
\text { based so that it cannot be accessed anywhere, } \\
\text { and this system is still general for periodic } \\
\text { inspection vehicles not specifically for bus } \\
\text { inspection. }\end{array}$ \\
\hline Researcher & Mohammad Rosul, Yudie Irawan \\
\hline $\begin{array}{l}\text { Journal } \\
\text { Title }\end{array}$ & $\begin{array}{l}\text { Sistem Informasi Pengujian Kendaraan } \\
\text { Bermotor Dinas Perhubungan Komunikasi Dan } \\
\text { Informatika Kabupaten Kudus }\end{array}$ \\
\hline $\begin{array}{l}\text { Journal } \\
\text { Published }\end{array}$ & Prosiding SNATIF Ke -1 Tahun 2014 [9] \\
\hline Conclusion & $\begin{array}{l}\text { Conclusion: The study produced a Motorized } \\
\text { Vehicle Testing Information System } \\
\text { application program that has a main menu } \\
\text { module consisting of files (log out and exit), } \\
\text { master data (applicant data, vehicle data, levy } \\
\text { data, vehicle type data and user data), testing, } \\
\text { payment and report. } \\
\text { Adventages: The administration process is } \\
\text { computerized } \\
\text { Weaknesses: still desktop base using VB.net, } \\
\text { not web-based so that they cannot be accessed } \\
\text { anywhere, and this system is still general for } \\
\text { periodic inspection vehicles not specifically for } \\
\text { bus inspection. }\end{array}$ \\
\hline Researcher & Nurhayati, Budi Serasi Ginting \\
\hline $\begin{array}{l}\text { Journal } \\
\text { Title }\end{array}$ & $\begin{array}{l}\text { Perancangan Sistem Informasi Pengujian } \\
\text { Kendaraan Bermotor Pada Dinas Perhubungan } \\
\text { Kabupaten Langkat }\end{array}$ \\
\hline \begin{tabular}{|l} 
Journal \\
Published
\end{tabular} & KAPUTAMA, Vol.7 No.2, Januari 2014 [6] \\
\hline Conclusion & $\begin{array}{l}\text { Conclusion: With a system designed this can } \\
\text { help people or owners of vehicles for } \\
\text { registration administration processes, vehicle } \\
\text { data stored in the database, can present vehicle } \\
\text { data that has been tested if data search is } \\
\text { needed. and others can be handled faster. } \\
\text { Adventages: This application is web-based } \\
\text { Weaknesses: The interface of the application } \\
\text { is less user friendly and still uses PHP native, } \\
\text { and the system is still general for periodic } \\
\text { inspection vehicles not specifically for bus } \\
\text { inspection. }\end{array}$ \\
\hline
\end{tabular}

\section{RESULT AND DISCUSSION}

4.1 Running System Analysis

Analysis of the running system is by making an activity diagram of the bus inspection process, as illustrated below: 


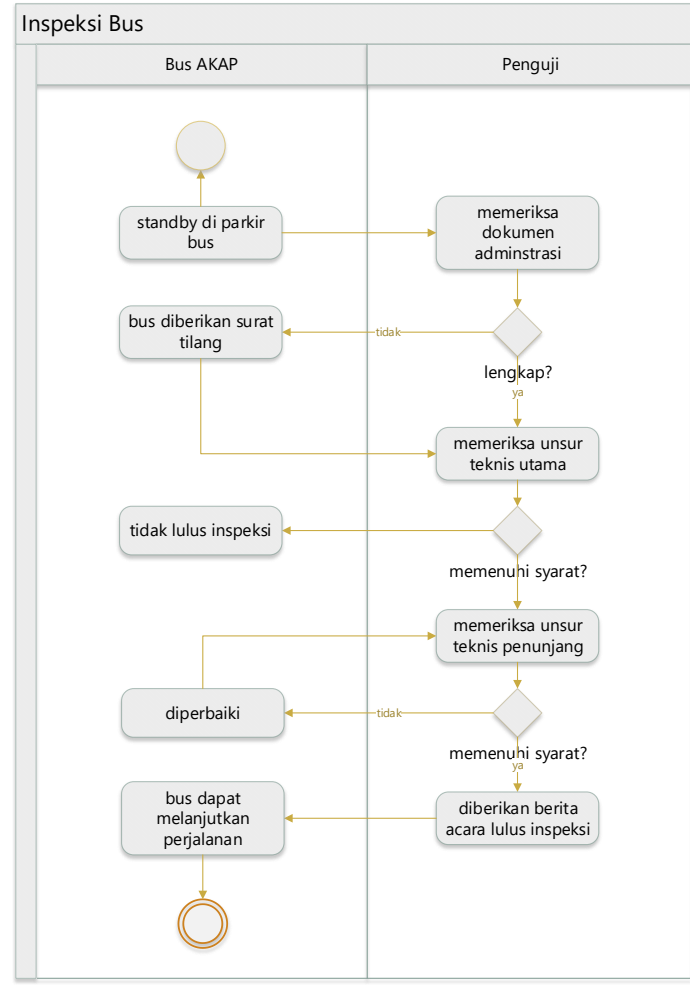

Fig 2 . Activity diagram of the bus inspection process

The activity diagram of the bus inspection process is explained as follows:

1. The bus parking in parking area.

2. The officer checks the administrative document of the bus.

3. If the administration of the bus is incomplete, the Civil Servant Investigator (PPNS) give the viollation letter, but the bus can still allow to take bus inspection.

4. The officer inspects the main technical element of the bus, consist of lighting systems, braking systems, vehicle bodies, tires, speed gauges, safety belt equipment, wipers and emergency response equipment.

5. If the inspection of main technical element is passed, the officer continues to inspects the supporting elements of the bus, consist of additional lighting systems, vehicle body parts, seating capacity, and other equipment.

6. If there is one or some parts of the supporting elements of the bus are not completed, the bus inspection is still passed with recommendation to complete the supporting element and the bus is permitted to enter the departure area of Pulo Gebang Bus Station.

7. The officer records the result of bus inspections into the bus inspection book.

\subsection{Identification of problems}

Table 2. Identification of problems with PIECES Method

\begin{tabular}{|c|c|l|l|}
\hline No & PIECES & Running System & Proposed System \\
\hline 1 & Performance & $\begin{array}{l}\text { The inspection } \\
\text { officer is still } \\
\text { doing inspections } \\
\text { manually so its } \\
\text { rather longer. }\end{array}$ & $\begin{array}{l}\text { Bus inspection is } \\
\text { doing by input } \\
\text { data into the } \\
\text { application so it } \\
\text { will be stored in } \\
\text { the database }\end{array}$ \\
\hline
\end{tabular}

\begin{tabular}{|c|c|c|c|}
\hline 2 & Information & $\begin{array}{l}\text { Bus inspection } \\
\text { results were } \\
\text { recorded manually } \\
\text { so the bus } \\
\text { inspection data } \\
\text { cannot be } \\
\text { presented well }\end{array}$ & $\begin{array}{l}\text { Bus inspection } \\
\text { data can be seen } \\
\text { directly in the } \\
\text { application, and } \\
\text { the bus inspection } \\
\text { report can be } \\
\text { created } \\
\text { automatically }\end{array}$ \\
\hline 3 & Economics & $\begin{array}{l}\text { The use of paper } \\
\text { and stationary on } \\
\text { every bus } \\
\text { inspection causing } \\
\text { need more } \\
\text { inspection cost }\end{array}$ & $\begin{array}{l}\text { Bus inspections } \\
\text { conducted by } \\
\text { input data into the } \\
\text { application so that } \\
\text { reduce the cost }\end{array}$ \\
\hline 4 & Control & $\begin{array}{l}\text { Leaders cannot } \\
\text { perform control or } \\
\text { monitoring of bus } \\
\text { inspections } \\
\text { because the } \\
\text { inspection officer } \\
\text { did not make a } \\
\text { report }\end{array}$ & $\begin{array}{l}\text { Leaders can } \\
\text { directly control or } \\
\text { monitor the bus } \\
\text { inspection process } \\
\text { in the application }\end{array}$ \\
\hline 5 & Efficiency & $\begin{array}{l}\text { Bus inspections } \\
\text { results were } \\
\text { recorded manually } \\
\text { to the report. }\end{array}$ & $\begin{array}{l}\text { The application } \\
\text { simplify the } \\
\text { process of } \\
\text { inputting and } \\
\text { reporting of } \\
\text { inspection results. }\end{array}$ \\
\hline 6 & Service & $\begin{array}{l}\text { Bus inspection } \\
\text { process is } \\
\text { complicated } \\
\text { because the officer } \\
\text { should always } \\
\text { borrow an } \\
\text { administrative } \\
\text { documents of each } \\
\text { busses even } \\
\text { though the bus had } \\
\text { been recorded. }\end{array}$ & $\begin{array}{l}\text { The officer no } \\
\text { need to borrow } \\
\text { the administrative } \\
\text { documents } \\
\text { because the data } \\
\text { was stored in the } \\
\text { application } \\
\text { database, so the } \\
\text { process is easier }\end{array}$ \\
\hline
\end{tabular}

\subsection{Proposed System Design}

After analyzing the running system and identifying problems so the next step is proposing the system design as needed in making web-based application. In this proposed system, the modeling language used is the Unified Modeling Language (UML).

\subsection{Use Case Diagram}

Use case diagram describes the interaction between users and systems or applications [3]. There are two actors in the proposed use case diagram, are Leader as Admin and Officer as User: 


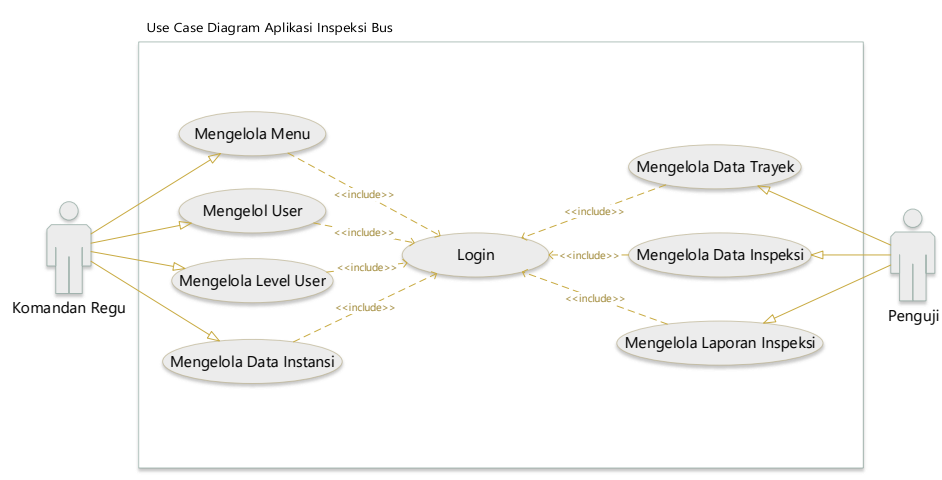

Fig 3. Use case diagram of the application

In figure of use case diagram above, there are two actors, Leader as Admin and Officer as Inspector. Identification of actor is explained in the table below:

Table 3. Identification of actor

\begin{tabular}{|c|c|l|}
\hline No & $\begin{array}{c}\text { Actor } \\
\text { name }\end{array}$ & \multicolumn{1}{c|}{ Description } \\
\hline 1 & Leader & $\begin{array}{l}\text { The leader is an actor who has the authority } \\
\text { to manage menus, manage users, manage } \\
\text { user levels and manage agency data. Leader } \\
\text { has the right to full access to the application }\end{array}$ \\
\hline 2 & Officer & $\begin{array}{l}\text { The officer are actors given access rights by } \\
\text { the leader primarily to manage bus route } \\
\text { data, and manage bus inspection data and } \\
\text { manage bus inspection reports }\end{array}$ \\
\hline
\end{tabular}

Table 4. The description of use case diagram

\begin{tabular}{|c|c|c|c|}
\hline No & $\begin{array}{c}\text { Name } \\
\text { Use Case }\end{array}$ & Description & Actor \\
\hline 1 & Login & $\begin{array}{l}\text { The application display the first } \\
\text { login page, leader and officer } \\
\text { input email and password in the } \\
\text { fields, if account correct the } \\
\text { system will display the } \\
\text { dashboard of application }\end{array}$ & $\begin{array}{l}\text { Leader } \\
\text { / } \\
\text { Officer, } \\
\text { System }\end{array}$ \\
\hline 2 & $\begin{array}{l}\text { Manage } \\
\text { Menus }\end{array}$ & $\begin{array}{l}\text { The application will display the } \\
\text { menus data, Leader can create, } \\
\text { update and delete menus data. }\end{array}$ & $\begin{array}{l}\text { Leader, } \\
\text { System }\end{array}$ \\
\hline 3 & $\begin{array}{l}\text { Manage } \\
\text { Users }\end{array}$ & $\begin{array}{l}\text { The application will display the } \\
\text { users data, Leader can create, } \\
\text { update and delete users data. }\end{array}$ & $\begin{array}{l}\text { Leader, } \\
\text { System }\end{array}$ \\
\hline 4 & $\begin{array}{l}\text { Manage } \\
\text { User } \\
\text { Level }\end{array}$ & $\begin{array}{l}\text { The application will display the } \\
\text { user levels data, Leader can } \\
\text { create, update and delete user } \\
\text { levels data, and grant } \\
\text { permission to the officer in } \\
\text { accordance with user level }\end{array}$ & $\begin{array}{l}\text { Leader, } \\
\text { System }\end{array}$ \\
\hline 5 & $\begin{array}{l}\text { Manage } \\
\text { Agency } \\
\text { Data }\end{array}$ & $\begin{array}{l}\text { The application will display the } \\
\text { agency data to be header of } \\
\text { reports, Leader update the } \\
\text { agency data. }\end{array}$ & $\begin{array}{l}\text { Leader, } \\
\text { System }\end{array}$ \\
\hline 6 & $\begin{array}{l}\text { Manage } \\
\text { Bus } \\
\text { Route } \\
\text { Data }\end{array}$ & $\begin{array}{l}\text { The application will display the } \\
\text { bus route data, Officer can } \\
\text { create, update and delete bus } \\
\text { route data. }\end{array}$ & $\begin{array}{l}\text { Officer, } \\
\text { System }\end{array}$ \\
\hline 7 & $\begin{array}{l}\text { Manage } \\
\text { Inspection } \\
\text { Data }\end{array}$ & $\begin{array}{l}\text { The application will display the } \\
\text { bus inspections data, Officer } \\
\text { can create, update and delete }\end{array}$ & $\begin{array}{l}\text { Officer, } \\
\text { System }\end{array}$ \\
\hline
\end{tabular}

\begin{tabular}{|c|l|l|l|}
\hline & & bus bus inspection data. & \\
\hline 8 & $\begin{array}{l}\text { Print } \\
\text { inspection } \\
\text { reports }\end{array}$ & $\begin{array}{l}\text { The application will display the } \\
\text { report of inspections data } \\
\text { according to inspection periode. }\end{array}$ & $\begin{array}{l}\text { Officer, } \\
\text { System }\end{array}$ \\
\hline
\end{tabular}

The use case scenario aims to explain the actor actions with the activities of the proposed system. Some of use case scenario of the application are explained in the table below:

Table 5. Use case scenario of manage inspection

\begin{tabular}{|c|c|c|}
\hline Use case name & \multicolumn{2}{|c|}{ Manage inspection data } \\
\hline Description & \multicolumn{2}{|c|}{$\begin{array}{l}\text { Officer can create, update and delete } \\
\text { bus inspection data }\end{array}$} \\
\hline Actor & \multicolumn{2}{|c|}{ Officer } \\
\hline Initial condition & \multicolumn{2}{|c|}{$\begin{array}{l}\text { Once logged in, the actor opens } \\
\text { manage inspection page }\end{array}$} \\
\hline \multicolumn{3}{|c|}{ Main scenario } \\
\hline \multicolumn{2}{|c|}{ Actor Action } & System Reaction \\
\hline \multirow{4}{*}{\multicolumn{2}{|c|}{$\begin{array}{l}\text { 1. Select manage inspection } \\
\text { menu } \\
\text { 2. Input the inspection data } \\
\text { by filling out the } \\
\text { inspection data form } \\
\text { 3. Update the inspection } \\
\text { data } \\
\text { 4. Delete the inspection data }\end{array}$}} & 1. Display manage \\
\hline & & $\begin{array}{l}\text { 2. Display input form of } \\
\text { inspection data } \\
\text { 3. Save inspection data into }\end{array}$ \\
\hline & & $\begin{array}{l}\text { the database } \\
\text { (tbl_rampcek) }\end{array}$ \\
\hline & & $\begin{array}{l}\text { 4. Display the inspection } \\
\text { data on manage } \\
\text { inspection page }\end{array}$ \\
\hline $\begin{array}{l}\text { Alternative } \\
\text { scenario }\end{array}$ & \multicolumn{2}{|r|}{ 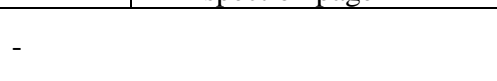 } \\
\hline Final condition & \multicolumn{2}{|c|}{$\begin{array}{l}\text { The inspection data successfully saved } \\
\text { and appear in the manage inspection } \\
\text { data page }\end{array}$} \\
\hline
\end{tabular}

Table 6. Use case scenario of print inspection report

\begin{tabular}{|c|c|c|}
\hline Use case name & \multicolumn{2}{|c|}{ Print inspection report } \\
\hline Description & \multicolumn{2}{|c|}{ Print inspection report into PDF file } \\
\hline Actor & \multicolumn{2}{|c|}{ Officer } \\
\hline Initial condition & \multicolumn{2}{|c|}{$\begin{array}{l}\text { Once logged in, the actor opens } \\
\text { inspection report page }\end{array}$} \\
\hline \multicolumn{3}{|c|}{ Main scenario } \\
\hline \multicolumn{2}{|c|}{ Actor Action } & System Reaction \\
\hline \multicolumn{2}{|c|}{$\begin{array}{l}\text { 1. Select inspection reports } \\
\text { menu } \\
\text { 2. Choose the period of } \\
\text { inpection report } \\
\text { 3. Print inspection report } \\
\text { into a pdf file }\end{array}$} & $\begin{array}{l}\text { 1. Display inspection report } \\
\text { page } \\
\text { 2. Display inspection report } \\
\text { data based on the } \\
\text { selected period } \\
\text { 3. Generate } \text { Pdf file of } \\
\text { inspection reports }\end{array}$ \\
\hline $\begin{array}{l}\text { Alternative } \\
\text { scenario }\end{array}$ & \multicolumn{2}{|r|}{ 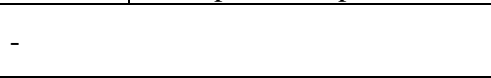 } \\
\hline Final condition & \multicolumn{2}{|c|}{$\begin{array}{l}\text { Display inspection report based on the } \\
\text { selected period and generate Pdf file }\end{array}$} \\
\hline
\end{tabular}

\subsection{Activity Diagram}

Activity diagram is an activity flow diagram in the system that is being designed, which will be used by the application system created [3]. Some of activity diagram of the application are shown below: 


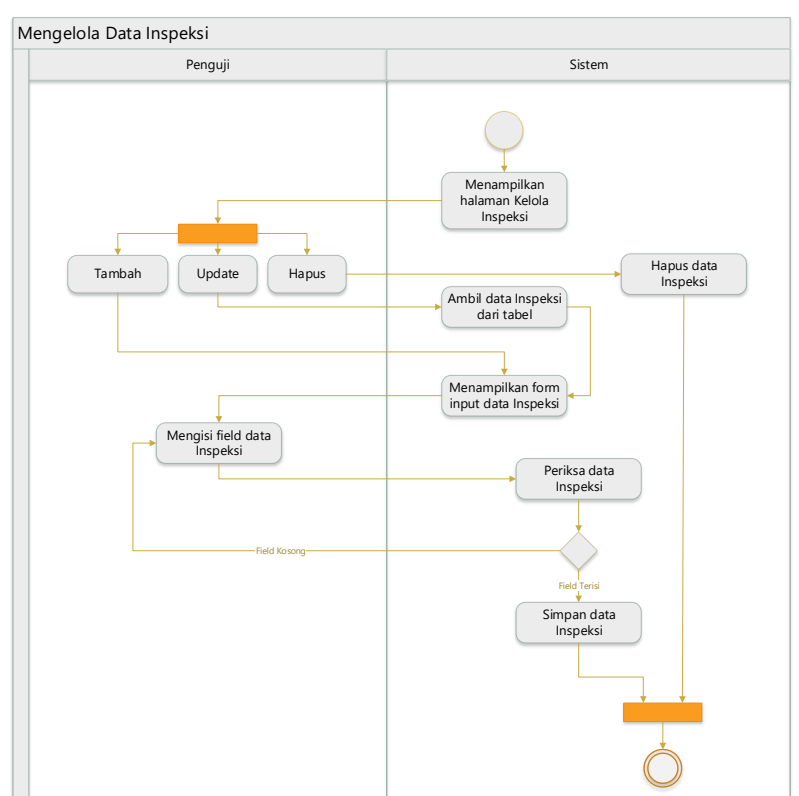

Fig 4. Activity diagram of manage inspection data

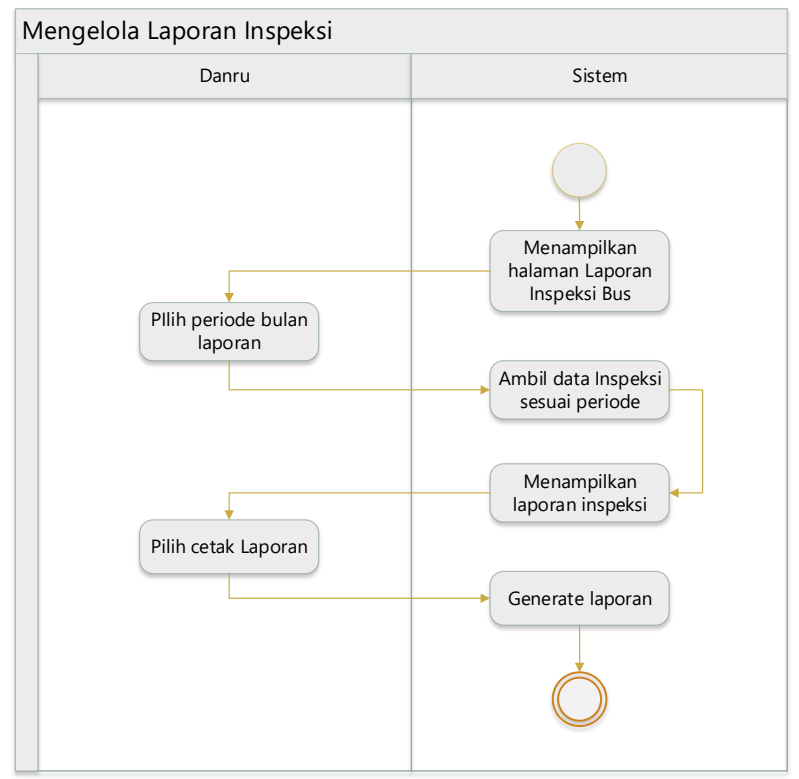

Fig 5. Activity diagram of print inspection report

\subsection{Sequence Diagram}

Sequence Diagram is a diagram that is associated with use cases where sequence diagrams show what stages should occur in a use case [3]. Some of sequence diagram of the application are shown below:

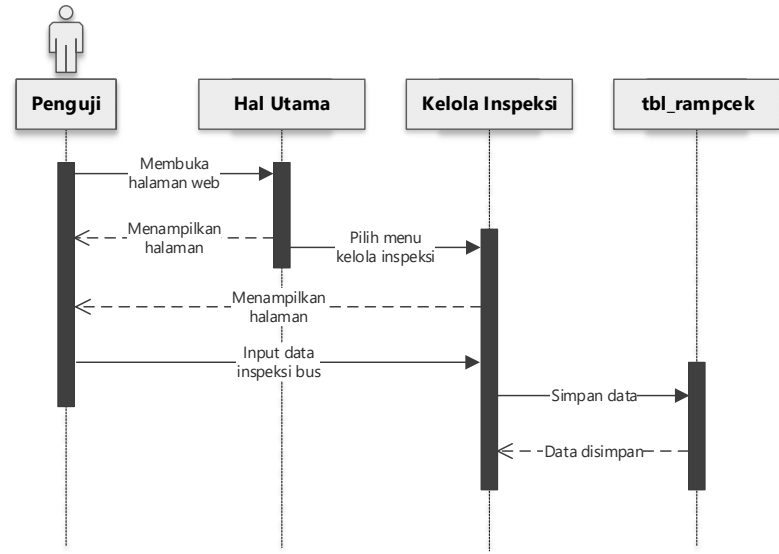

Fig 6. Sequence diagram of manage inspection data

The sequence diagram of manage inspection data is explained as follows:

After logging in and the system display dashboard page, Officer select the "manage inspection" menu, then the system will display a bus inspection data, if the user clicks add then the form will display an inspection form that will be inputted by the user, after the user inputs the data, it will be stored by the system into the database, then the system will return to the inspection data page.

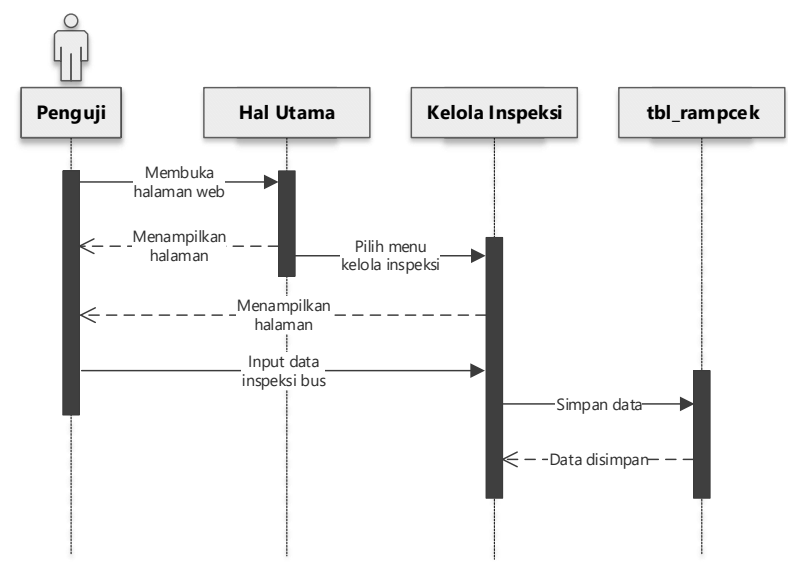

Fig 7. Sequence diagram of print inspection report

The sequence diagram of print inspection report is explained as follows:

After logging in and the system display dashboard page, Officer select the "inspection report" menu, then the system will display the report page. Officer determine the reporting month period, then the system will retrieve data from the database and will generate a repor.

\subsection{Class Diagram}

Designing database specifications is a step to map the conceptual model to the database model that will be used [3]. The design of the bus inspection application database is described in the UML Class Diagram model. The class diagram of the application is shown below: 


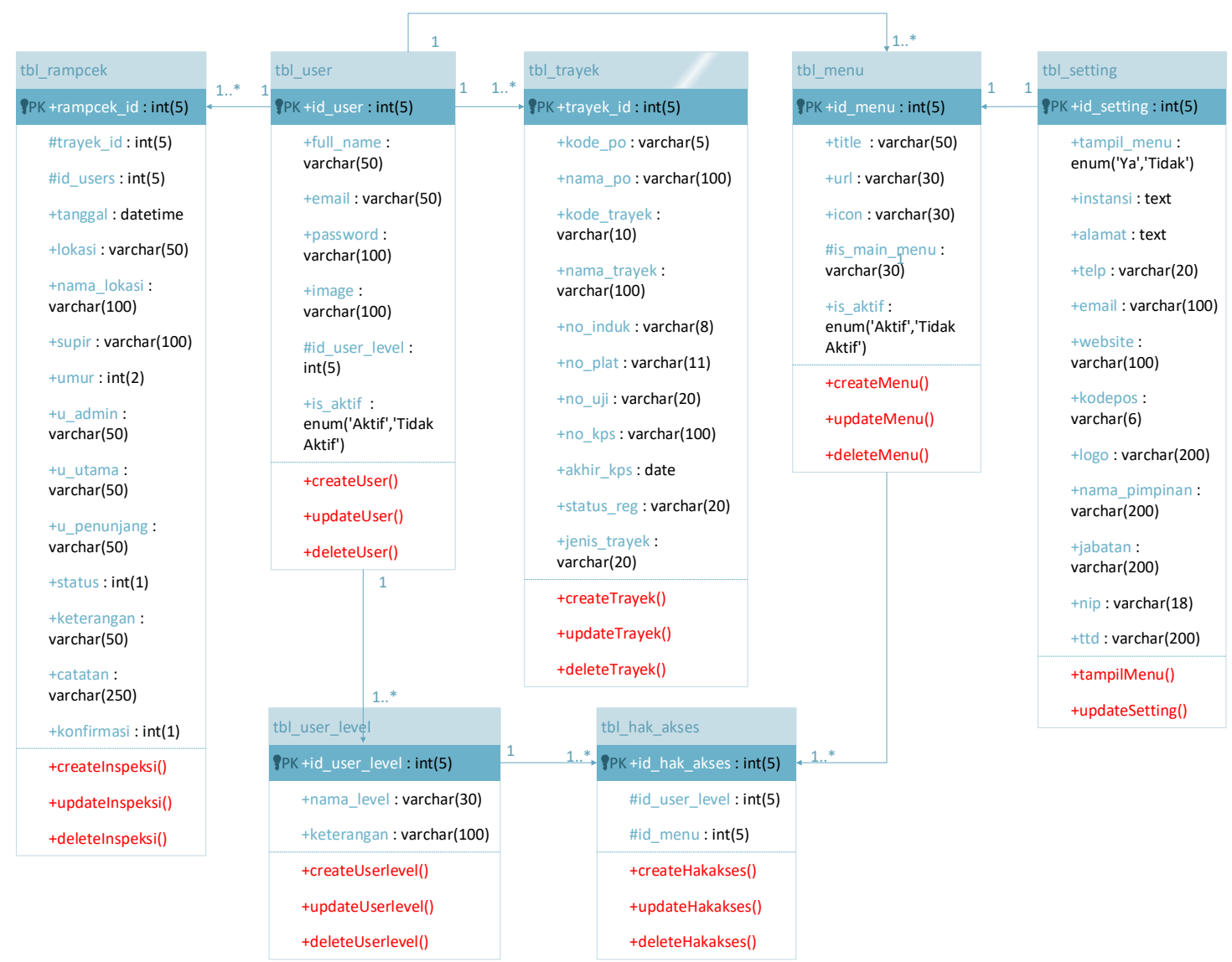

Fig 8. Class diagram of the application

The explanation of Table tbl_rampcek according to class diagram above:

Table 7. Table tbl_rampcek (bus inspection)

\begin{tabular}{|c|l|l|r|l|}
\hline \multicolumn{2}{|l|}{ Table Name } & \multicolumn{1}{|l|}{ tbl_rampcek } \\
\hline No & Field Name & $\begin{array}{c}\text { Type of } \\
\text { Data }\end{array}$ & Lenght & \multicolumn{1}{|l|}{ Description } \\
\hline 1 & rampcek_id & integer & 5 & $\begin{array}{l}\text { Primary Key, } \\
\text { Auto Increment }\end{array}$ \\
\hline 2 & trayek_id & integer & 5 & $\begin{array}{l}\text { Foreign Key with } \\
\text { tbl_trayek }\end{array}$ \\
\hline 3 & id_users & integer & 5 & $\begin{array}{l}\text { Foreign Key with } \\
\text { tbl_user }\end{array}$ \\
\hline 4 & tanggal & datetime & $\begin{array}{l}\text { Date of input } \\
\text { inspection data }\end{array}$ \\
\hline 4 & lokasi & varchar & 50 & $\begin{array}{l}\text { Inspection } \\
\text { Location }\end{array}$ \\
\hline 5 & nama_lokasi & varchar & 100 & $\begin{array}{l}\text { Inspection } \\
\text { Location Name }\end{array}$ \\
\hline 6 & supir & varchar & 100 & Bus driver name \\
\hline 7 & umur & int & 2 & Bus driver age \\
\hline 8 & u_admin & varchar & 50 & $\begin{array}{l}\text { Administrtive } \\
\text { elements } \\
\text { inspection results }\end{array}$ \\
\hline 9 & u_utama & date & 50 & $\begin{array}{l}\text { Technical } \\
\text { elements } \\
\text { inspection results }\end{array}$ \\
\hline 10 & u_penunjang & varchar & 50 & $\begin{array}{l}\text { Supporting } \\
\text { elements } \\
\text { inspection results }\end{array}$ \\
\hline
\end{tabular}

\begin{tabular}{|l|l|l|r|l|}
\hline 11 & status & int & 1 & $\begin{array}{l}\text { Inspection Result } \\
\text { (Passed or Failed) }\end{array}$ \\
\hline 12 & keterangan & varchar & 50 & $\begin{array}{l}\text { Description of } \\
\text { Inspection }\end{array}$ \\
\hline 13 & catatan & varchar & 250 & Additional Notes \\
\hline 14 & konfirmasi & int & 1 & Confirmation \\
\hline
\end{tabular}

4.8 User Interface Design

User Interface design is to create a page display that will be used by the user to interact with the system using the interface on the computer screen. User interface design of this application is web-based using the PHP programming language with the Code Igniter framework. Some of user interface designs of the application are shown below: 
International Journal of Computer Applications Technology and Research Volume 7-Issue 12, 425-432, 2018, ISSN:-2319-8656

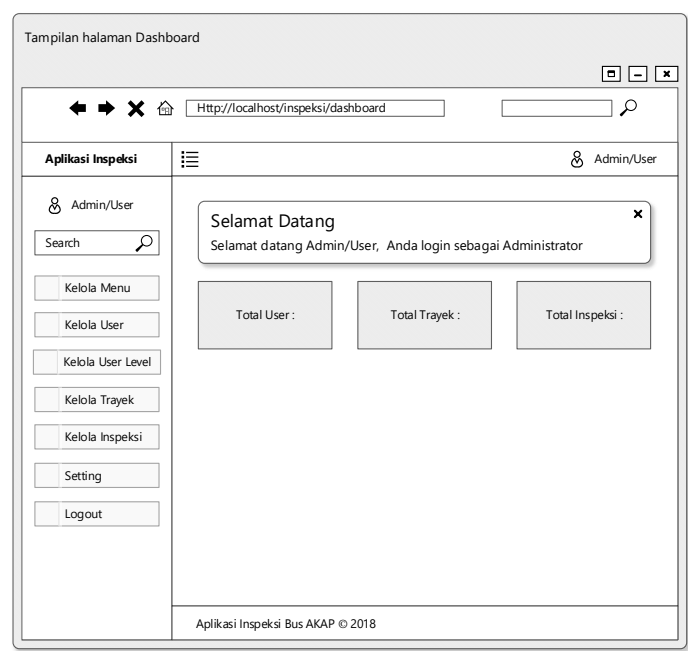

Fig 9. User Interface of dashboard

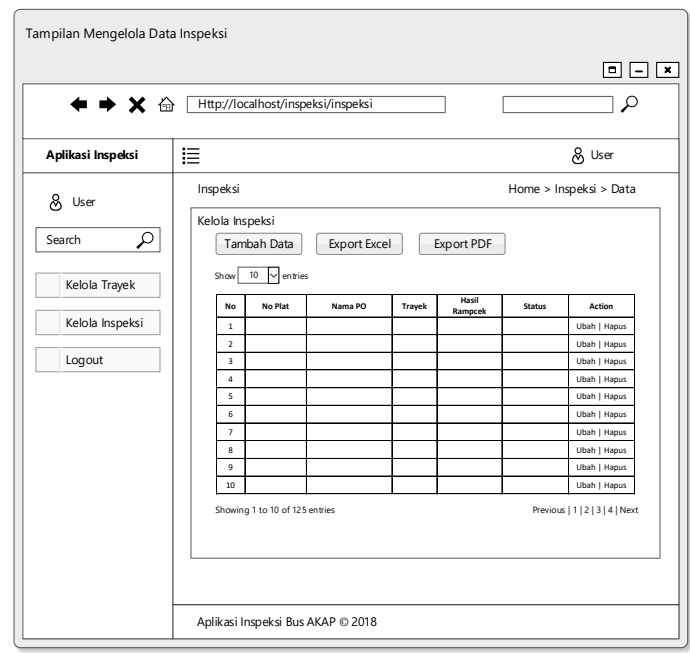

Fig 10. User Interface of manage inspection data

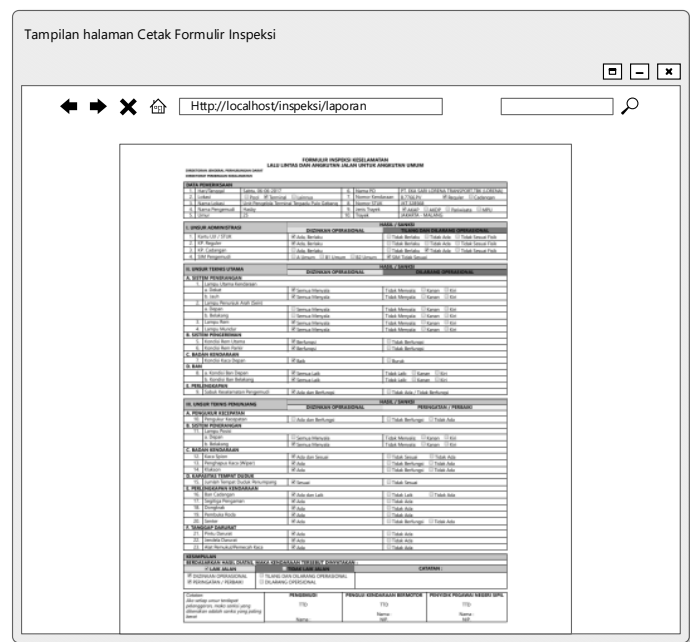

Fig 11. User Interface of bus inspection report

\subsection{Implementation}

The implementation is the stage where the system begins to be made using information that has been collected [3] at the implementation of information that has been previously collected is applied using a programming language and also besides that the implementation stage also discusses the testing of application systems that are intended to analyze the results of the test, whether the results are as planned. Some of implementation of database and user interface are shown below:

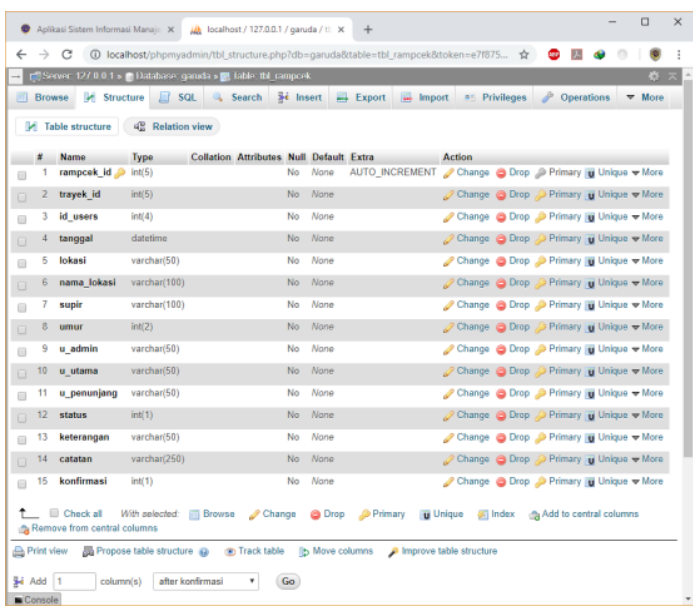

Fig 12. Implementation of inspection database (tbl_rampcek)

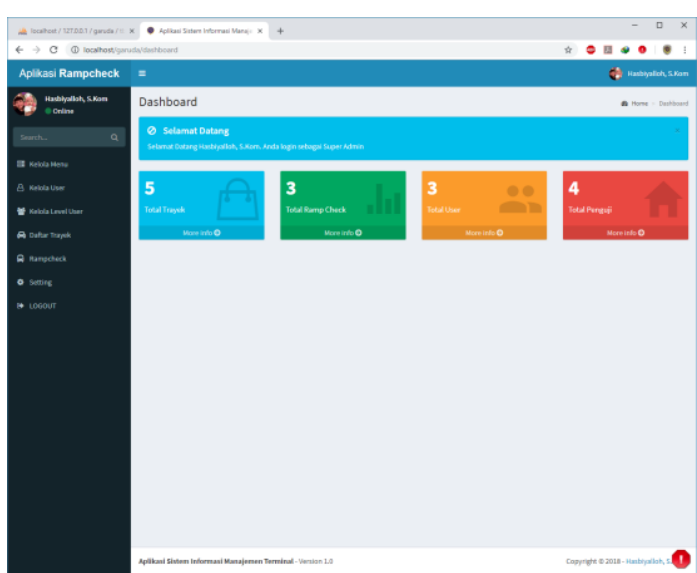

Fig 13. Implementation of Dashboard page

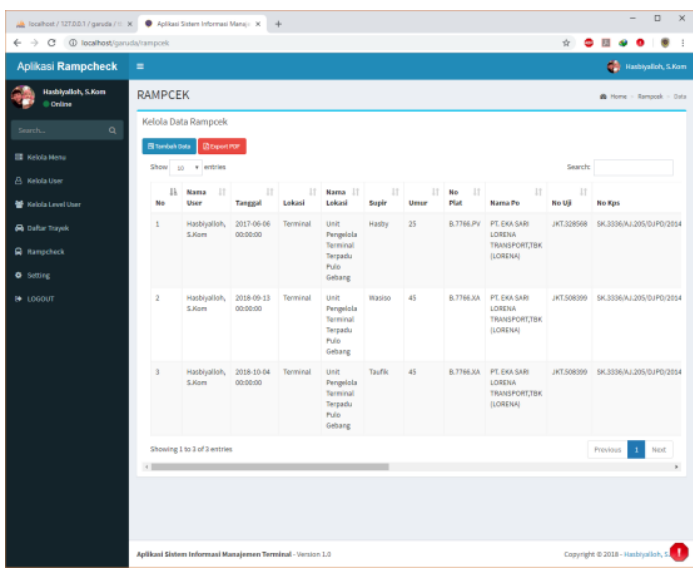

Fig 14. Implementation of Inspection data page 


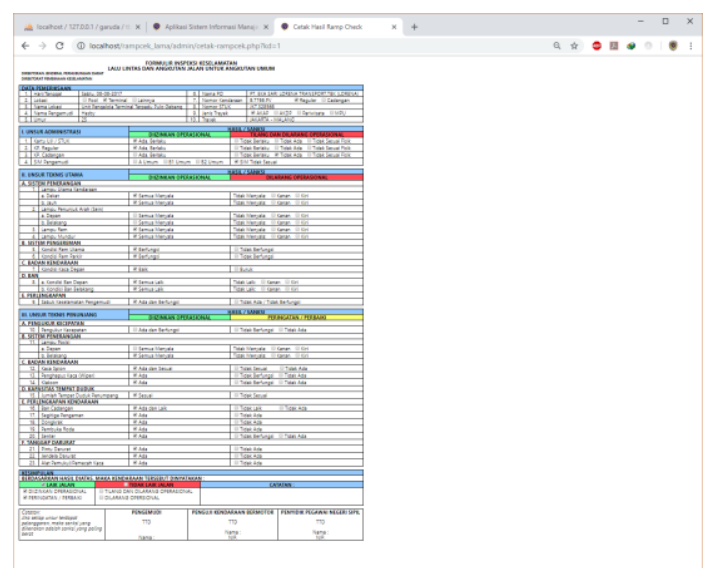

Fig 15. Implementation of Inspection report page

\section{CONCLUSION}

Conclusion of this research are:

1. Running system of bus inspection in the Pulo Gebang Bus Station still uses manual system that makes inspection files to fall apart, prone to loss or damage, difficult to find the history of bus inspection, and weak monitoring of inspection report.

2. By implementing the application, solve the existing problems in the bus inspection process by make it easier to input inspection data, print inspection reports, finding inspection history and simplify the work of employees and leaders in Pulo Gebang Bus Station.

\section{REFERENCES}

[1] Arikunto, Suharsimi. 2009. Manajemen Penelitian. Jakarta: PT. Rineka. Cipta.

[2] Dirjen Hubdat. 2017. Peraturan Direktur Jenderal Perhubungan Darat Nomor SK.5637/AJ.403/DRJD/2017 Tentang Pedoman Pelaksanaan Inspeksi Keselamatan Lalu Lintas dan Angkutan Jalan. Kementerian Perhubungan. Jakarta.

[3] Dennis, Alan. 2015. System Analysis and Design with UML 5th Edition. United States of America: John Wiley and Sons.

[4] Masya, F. Elvina, \& Simanjuntak, FM. 2012. Sistem Pelayanan Pengaduan Masyarakat pada Divisi Humas POLRI Berbasis Web. Jurnal Seminar Nasional Aplikasi Teknologi Informasi. 2012. [online] Available at:

<http://journal.uii.ac.id/Snati/article/download/2897/265 6> [Accessed on: 1 November 2018].

[5] M. Mishbah, D. I. Sensuse and H. Noprisson. 2017. Information system implementation in smart cities based on types, region, sub-area. ICITSI 2017, pp. 155-161. [online] Available <http://ieeexplore.ieee.org/stamp/stamp.jsp?tp=\&arnum ber $=8267935 \&$ isnumber $=8267903>$ [Accessed on: 20 Oktober 2018].

[6] Nurhayati dan Ginting, B.S. 2014. Perancangan Sistem Informasi Pengujian Kendaraan Bermotor Pada Dinas Perhubungan Kabupaten Langkat. KAPUTAMA 2014. pp.9-15. [online] Available at $<$ http://penelitian.kaputama.ac.id/images/sampledata/Fil e/Jurnal/Jurnal2014/ JURNAL2.pdf > [Accessed on: 2 Oktober 2018].

[7] Pemerintah Provinsi DKI Jakarta. 2016. Peraturan Gubernur Provinsi DKI Jakarta Nomor 336 Tahun 2016 Tentang Pembentukan, Organisasi dan Tata Kerja Unit Pengelola Terminal Terpadu Pulo Gebang. Berita Daerah Provinsi DKI Jakarta Tahun 2016 Nomor 62233. Sekretariat Daerah. Jakarta.

[8] Pressman, R.S. and Maxim, B.R. 2012. Software Engineering : a prcatitioner's approach. Eighth Edition. New York: McGraw-Hill.

[9] Rosul, M. dan Irawan, Y. 2014. Sistem Informasi Pengujian Kendaraan Bermotor Dinas Perhubungan Komunikasi dan Informatika Kabupaten Kudus. Prosidin SNATIF 2014. pp.437-444. [online] Available at:

<http://jurnal.umk.ac.id/index.php/SNA/article/downloa d/208/207> [Accessed on: 5 Oktober 2018].

[10] Samsinar dan Suryadi, L. 2014. Desain Sistem Informasi Pengujian Kendaraan Bermotor Pada UPT PKB Kendaraan Khusus Cilincing. SESINDO 2014. pp.219-224. [online] Available at $<$ http://is.its.ac.id/pubs/ oajis/index.php/file/download_file/1396> [Accessed on: 16 Oktober 2018].

[11] Zed, Mestika. 2008. Metode Penelitian Kepustakaan. Jakarta : Yayasan Obor. 